\title{
PENDING EU DISPUTES IN THE WTO: CHALLENGES TO EU ENERGY LAW AND POLICY
}

\begin{abstract}
Tamara Perišin*
Summary: In the last several years, there has been a surprising number of energy-related disputes in the WTO. In seven such cases, the EU has taken the role of respondent. There are four different groups of these cases: the first are disputes concerning EU standards on biofuels and other renewable energy sources; the second are disputes on EU Member State measures implementing these EU standards on biofuels and renewables; the third are cases directed against internal market measures in the field of energy; and the fourth concern EU anti-dumping duties. These disputes are vital, as they could affect the future of EU energy law and policy, with implications for the internal market, environmental protection and national security.
\end{abstract}

\section{Introduction}

During the last four years since the Croatian Yearbook of European Law and Policy published the last report on the European Union's (EU) pending cases in the World Trade Organization (WTO), there has, predictably, been a number of new disputes raised by and against the EU. While these disputes involve a number of other WTO members and cover many areas of WTO law, there are patterns to be seen.

Concerning the parties to these disputes, the EU has a relatively large number of trade disputes with the Russian Federation. Russia became a WTO member on 22 August 2012 and it took a bit less than a year for the EU to request the first consultations on 9 July 2013. Since then, in one year, a total of 5 disputes have been initiated between these members. One can also observe that the countries which appear as complainants or respondents against the EU also find themselves in reversed roles. For example, a number of currently pending disputes initiated by Russia, China, Argentina, Brazil, Indonesia, etc, against the EU is in loose correlation with the number of disputes that the EU has initiated against each of these members. This can partly be explained by the amount of trade between two countries, but that is not the only factor. The EU's trade with Japan, Australia or South Africa is substantial, but there are hardly any disputes with these countries. It can also be partly explained by the number and type of trade barriers (eg divergent legal

* Prof Tamara Perišin, MJur (Oxon), PhD, Faculty of Law, University of Zagreb. 
systems, administrative practices, etc). However, it also seems that one dispute between two countries triggers another one in the opposite direction ('revenge or warning litigation').

Regarding the substance of the disputes, it is striking how many of them that have arisen in recent years concern the energy sector. ${ }^{1}$ Energy disputes are a novelty in the WTO. As Marhold wrote, many considered that energy 'was at least de facto, and perhaps even de jure, excluded from GATT/WTO coverage'. ${ }^{2}$ She explains this by the fact that the major exporters of fossil fuels were not parties to the General Agreement on Tariffs and Trade (GATT), that companies trading in fossil fuels preferred settling disputes outside the WTO, and countries in general were treating energy as both an exhaustible natural resource and as a security question (both being justifications for a prima facie breach of GATT obligations). ${ }^{3}$ However, energy has actually always been covered by the GATT and it is nowadays covered by WTO law. In most of these new disputes on energy, the EU takes the role of the respondent. ${ }^{4}$ Unsurprisingly, both of Russia's requests for consultations with the EU concern energy measures. However, Russia, being a major exporter of energy to the EU, is not the only country voicing dissatisfaction with EU energy rules. China, Argentina and Indonesia have also requested consultations concerning some EU energy-related measures. These cases concern both EU internal measures having external effects, and external measures.

Due to the dominance of the energy-related disputes in the recent period, this report places them in its focus. These disputes are vital, as they could affect EU energy law and policy, with implications for the internal market, environmental protection and national security.

\footnotetext{
1 The pending energy related disputes are: WTO, European Union and a Member State: Certain Measures Concerning the Importation of Biodiesels, Complainant: Argentina (17 August 2012) DS443; WTO, European Union and Certain Member States: Certain Measures Affecting the Renewable Energy Generation Sector, Complainant: China (5 November 2012) DS452; WTO, European Union: Certain Measures on the Importation and Marketing of Biodiesel and Measures Supporting the Biodiesel Industry, Complainant: Argentina (15 May 2013) DS459; WTO, European Union: Anti-Dumping Measures on Biodiesel from Argentina, Complainant: Argentina (19 December 2013) DS473; WTO, European Union: Cost Adjustment Methodologies and Certain Anti-Dumping Measures on Imports from Russia, Complainant: Russian Federation (23 December 2013) DS474; WTO, European Union: Certain Measures Relating to the Energy Sector, Complainant: Russian Federation (30 April 2014) DS476; WTO, European Union: Anti-Dumping Measures on Biodiesel from Indonesia, Complainant: Indonesia (10 June 2014) DS480.

2 Anna Marhold, 'The World Trade Organization and Energy: Fuel for Debate' (2013) 2(8) ESIL Reflections 1.

3 ibid 2.

4 The EU was a complainant in WTO, Canada: Measures Relating to the Feed-in Tariff Program DS426, but that case is no longer pending as it has been decided. See WTO, Canada: Certain Measures Affecting the Renewable Energy Generation Sector \& Canada: Measures Relating to the Feed-In Tariff Program - Reports of the Appellate Body (6 May 2013) WT/ $\mathrm{DS} 412 / \mathrm{AB} / \mathrm{R}$ and WT/DS426/AB/R.
} 


\section{The EU's pending energy disputes in the WTO}

There are currently seven disputes initiated against the EU which in some way concern energy rules. They have been raised by four different countries: Argentina ( 3 requests for consultations), Russia (2 requests for consultations), and China and Indonesia (each with 1 request for consultations). All of these cases are still at the stage of consultations so there is little publicly available information on the application of the challenged measures and the reasons for the challenge.

There are four different types of energy-related cases: the first are disputes concerning EU standards on biofuels and other renewable energy sources; the second are disputes on EU Member State measures implementing these EU standards on biofuels and renewables; the third are cases directed against internal market measures in the field of energy; and the fourth concern EU anti-dumping duties.

\subsection{Disputes on biofuels and other renewables}

EU rules on renewable energy, and particularly the importation of biodiesel, are the object of 3 requests for consultations. ${ }^{5}$ The EU has been one of the pioneers among the developed countries in seeking to reduce greenhouse gas (GHG) emissions. In general, the EU is committed to a high level of protection of the environment and seeks to achieve this through a number of policies. ${ }^{6}$ In the field of energy, however, stimulating the use of biofuels and other renewables is also motivated by the EU's desire to reduce its dependence on foreign oil and gas. ${ }^{7}$ The EU has limited reserves of fossil fuels which are insufficient for its needs, so it is a net importer of both oil and gas. ${ }^{8}$ The imports of these goods are not seen as just trade in commodities, but as a matter of public security. Events such as the Arab Spring and the uprising in Libya or the recent Crimean crisis show how fragile Europe is in terms of energy supply. ${ }^{9}$ For example,

\footnotetext{
5 European Union and a Member State DS443 (n 1); European Union and Certain Member States DS452 (n 1); European Union - Certain Measures on the Importation and Marketing of Biodiesel and Measures Supporting the Biodiesel Industry DS459 (n 1).

6 Art 3(3) TEU; Arts 11, 114(3), 191 TFEU.

7 See eg Commission, 'Member States' Energy: An Indicator-Based Assessment' (European Economy, Occasional Papers 145) April 2013 <http://ec.europa.eu/economy_finance/ publications/occasional_paper/2013/pdf/ocp145_en.pdf> accessed 20 July 2014; Euractiv, 'EU Plans to Reduce Russian Energy Dependence' 21 March $2014<$ http:/ /www.euractiv.com/energy/eu-leaders-discuss-reducing-ener-news-534344> accessed 20 July 2014.

8 Commission, 'EU Energy in Figures (Statistical Pocketbook) 2013 <http://ec.europa. eu/energy/publications/doc/2013_pocketbook.pdf> accessed 13 July 2014; Commission, Monthly and Cumulated Crude Oil Imports (Volumes and Prices) by EU and non EU Country <http://ec.europa.eu/energy/observatory/oil/import_export_en.htm> accessed 13 July 2014.

9 See eg an analysis in The Economist, 'Conscious Uncoupling: Reducing Europe's Depen-
} 
the recent Ukrainian crisis is likely to stimulate the EU and its Member States to adopt additional measures to reduce reliance on Russian energy. Strengthening the requirement of energy efficiency and encouraging the use of renewable sources which could be produced anywhere in the world are among the expected steps in that direction.

Existing EU legislation and policies on renewable energy are extensive. The EU has set a target of $20 \%$ of renewable energy by 2020 (the so-called '20-20-20' goal). ${ }^{10}$ There are more detailed sectoral rules imposing additional requirements. For example, in the field of transport, the Biofuels Directive required Member States to have a minimum of $5.75 \%$ of renewable energy by $2010^{11}$ and the Renewable Energy Directive increases that percentage to $10 \%$ by $2020 .{ }^{12}$ The Renewable Energy Directive supports only the use of certain types of biofuels - these should be sustainable biofuels whose production does not cause an increase in greenhouse gas (GHG) or does not harm biodiversity. ${ }^{13}$ In addition, the Commission wanted to stimulate the development of new generation biofuels and prevent indirect land-use change (which also causes GHG and also pushes up food prices) so it proposed a new Indirect Land-Use Change (ILUC) Directive. This Directive would amend the Renewable Energy Directive by requiring that food-based biofuels could only represent $5 \%$ of the renewable energy target for transport. ${ }^{14}$ The Council did not accept this proposal, ${ }^{15}$ but it recently yielded to a compromise that non-food biofuels can be $7 \%$ of the target for transport. ${ }^{16}$ The proposal has yet to

dence on Russian Gas Is possible - But It Will Take Time, Money and Sustained Political Will' The Economist (London, 5 April 2014) <www.economist.com/news/briefing/21600111-reducing-europes-dependence-russian-gas-possiblebut-it-will-take-time-money-and-sustained $>$ accessed 13 July 2014.

10 Directive 2009/28/EC of the European Parliament and of the Council of 23 April 2009 on the promotion of the use of energy from renewable sources and amending and subsequently repealing Directives 2001/77/EC and 2003/30/EC [2009] OJ L140/16 (hereinafter: the Renewable Energy Directive).

11 Art 3(1)ii Directive 2003/30/EC of the European Parliament and of the Council of 8 May 2003 on the promotion of the use of biofuels or other renewable fuels for transport [2003] OJ L123/42 (hereinafter: Biofuels Directive). Member States were required to reach this aim by 2010 .

12 Art 3(4) Renewable Energy Directive (n 10).

13 Preamble, recital 65-80, Art 17 Renewable Energy Directive (n 10).

14 Art 2(2) c)ii) Proposal for a Directive of the European Parliament and of the Council amending Directive 98/70/EC relating to the quality of petrol and diesel fuels and amending Directive 2009/28/EC on the promotion of the use of energy from renewable source, $2012 / 0288$ (COD), on what was proposed to become Art 3(4)d of the amended Renewable Energy Directive (n 10).

15 Council of the European Union, 'Press Release: 3282nd Council Meeting - Transport, Telecommunications and Energy', 12 December 2013, 17710/13 PRESSE 571, PR CO 67.

16 Council of the European Union, Proposal for a Directive of the European Parliament and of the Council amending Directive 98/70/EC relating to the quality of petrol and diesel fuels and amending Directive 2009/28/EC on the promotion of the use of energy from 
be accepted by the European Parliament which had previously supported a $6 \%$ cap. $^{17}$

From a trade law perspective, rules on biofuels and renewables present obstacles to trade. Rules which stimulate the use of renewables limit trade in oil, gas and other fossil fuels. Rules which stimulate only a certain type of renewables (eg new generation biofuels) limit trade in other renewables, as well as in fossil fuels. The main question for the pending disputes is to what extent this is WTO-compliant. WTO law certainly does not (even prima facie) ban all obstacles to international trade or all impediments to market access, but it does ban protectionism and certain other unnecessary obstacles to trade. Requests for consultations invoke numerous provisions of the GATT, the Agreement on Technical Barriers to Trade (TBT), the Agreement on Trade-Related Investment Measures (TRIMs), the Subsidies Agreement, etc. The disputes are at too early a stage and there is not enough material to judge whether the objections are founded. However, the crux of the disputes will be on whether EU rules are protectionist.

It is incontestable that the EU does not have enough fossil fuels for its needs, so these are mostly imported. Promoting the use of biofuels and other renewable sources also means that the EU is seeking to improve its own energy production potential, thus leading to fewer imports and less dependence on another country. In addition, in relation to foreign biofuels producers, it is certainly true that the EU domestic biofuels industry was exerting pressure on the EU legislature, eg to increase the proposed cap on food-based biofuels from $5 \%$ to $6 \%$ or $7 \% .{ }^{18}$ It seems that there is a significant number of EU-based biofuels producers who were relying on a future increase in the use of their product, so they were also not in favour of a cap, and they might have had a role in determining what the cap would be. Pressure from a lobby is not in itself proof of any protectionism, but there might be instances where a lobby provides the regulator with sufficient information on domestic production so that a facially neutral rule could be drafted to serve domestic producers and protect them against imports. For example, in one of the cases, Argentina objects to a provision of the Renewable Energy Directive according to which only biofuels and bioliquids that save $35 \%$ or more of GHG are considered sustainable and count towards meeting national targets

renewable sources (first reading) - Political agreement, 2012/0288 (COD), Brussels, 3 June 2014.

17 European Parliament, 'Press Release: European Parliament Backs Switchover to Advanced Biofuels', 11 September 2013.

18 See eg Charlie Dunmore, 'Industry Seeks to Weaken EU Cap on Crop-based Fuels', Reuters, 14 October 2012 <http://uk.reuters.com/article/2012/10/14/uk-eu-biofuelsidUKBRE89DOIN20121014> accessed 13 July 2014. 
and obligations and are eligible for financial support. ${ }^{19}$ Argentina claims that this percentage is set arbitrarily. ${ }^{20}$ While it is true that the Directive also increases this percentage from the year 2017 to $50 \%$ and from 2018 to $60 \%{ }^{21}$ so there is an environmental benefit, the reason for setting a sharp distinction between, for example, a biofuel with $34 \%$ and one with $36 \%$ GHG savings is not clear. If one determines that EU producers are predominantly those having savings of $35 \%$ of GHG while foreigners are those below that threshold, that would be a significant indication of protectionism. ${ }^{22}$ A progressive differentiation of biofuels which could link the amount of financial support to the percentage of GHG savings would probably satisfy Argentina.

\subsection{Disputes on national implementing rules on renewables}

For international trade, it is relevant that EU law in the field of energy and renewables mostly consists of directives. As Article 288(3) TFEU states, directives bind Member States as to the result to be achieved, and leave them the choice of form and methods. This means that each EU Member State is supposed to have its own national implementing rules which bring about the results set out in directives. States have, thus, adopted various rules seeking to promote the use of renewable energy so as to meet the binding targets. These State-level implementing rules can themselves present obstacles to both the EU's internal and external trade so there have been both intra-EU cases where national implementing measures have been challenged before the $\mathrm{CJEU}^{23}$ and those where such measures have been challenged in the WTO.

There are currently two the pending WTO disputes on energy where consultations were requested precisely concerning EU Member State measures. ${ }^{24}$ Argentina requested consultations on a Spanish measure

\footnotetext{
19 Art 17(2) Renewable Energy Directive (n 10). WTO, European Union and Certain Member States - Certain Measures on the Importation and Marketing of Biodiesel and Measures Supporting the Biodiesel Industry - Request for Consultations by Argentina (15 May 2013) WT/ DS459/ 1 .

20 European Union and Certain Member States - Certain Measures on the Importation and Marketing of Biodiesel and Measures Supporting the Biodiesel Industry (n 19).

21 Art 17(2) Renewable Energy Directive (n 10).

22 Cf with cases on different tax rates which were applied facially neutrally to domestic and imported products, but were in vioation of WTO law: WTO, Japan: Tax on Alcoholic Beverages - Report of the Appellate Body (4 October 1996) WT/DS/8,10-11/ AB/R; WTO, Chile: Taxes on Alcoholic Beverages - Report of the Appellate Body (13 December 1999) WT/ $\mathrm{DS} 87 / \mathrm{AB} / \mathrm{R}, \mathrm{WT} / \mathrm{DS} 110 / \mathrm{AB} / \mathrm{R}$.

${ }^{23}$ Case C-204/12 Essent $v$ Belgium, judgment of 11 September 2014.

24 European Union and a Member State - Certain Measures Concerning the Importation of Biodiesels, DS443 (n 1); European Union and Certain Member States - Certain Measures Affecting the Renewable Energy Generation Sector, DS452 (n 1).
} 
on the allocation of quantities of biodiesel needed to achieve the mandatory target of renewable energy. According to the Argentinean request for consultations, the Spanish measure 'provides that computing for mandatory biofuel targets may only be conducted in relation to biodiesel produced entirely in plants located on the territory of Spain or of another EU Member State'. ${ }^{25}$ Argentina has an incentive to challenge this since it is a large biodiesel producer and it mostly exports this into the EU, primarily into Spain, and it argues that the Spanish measure is protectionist. ${ }^{26}$ In another case targeted against an EU Member State, China requested consultations on Italian and Greek measures concerning feed-in tariffs. Feed-in tariffs are a model of stimulating production of renewable energy by paying those who produce green energy and send it to the grid, and under certain conditions even when they use this energy themselves. Many other cases also refer to both EU and state measures, but in those cases the EU measure is the main cause of the dispute. ${ }^{27}$

In these disputes, the EU represents both itself and its Member States, and the European Commission is the one to plead the case in any WTO proceedings. However, an unfavourable Panel or Appellate Body report might not be relevant for the whole of the EU if only a national measure and not an EU one is found to be inconsistent with WTO law.

\subsection{Disputes on energy measures aimed at the establishment and functioning of the internal market}

There are also energy related disputes that do not concern the EU high standards on GHG, but measures primarily aimed at the establishment and functioning of the internal market. With this proclaimed aim, the EU adopted the so-called 'Third Energy Package' of directives and regulations requiring the unbundling of the production, supply and transmission of electricity and natural gas. ${ }^{28}$ The measures are primarily intended to make the energy market more competitive, and to reduce prices (and are mostly adopted on internal market legal bases).

Russia requested consultations concerning this EU package and the national implementing measures, particularly concerning 'discriminatory certification requirements in relation to third countries, and the require-

\footnotetext{
25 WTO, European Union and a Member State: Certain Measures Concerning the Importation of Biodiesels - Request for Consultations by Argentina (23 August 2012) WT/DS443/1.

26 ibid.

27 European Union: Certain Measures on the Importation and Marketing of Biodiesel and Measures Supporting the Biodiesel Industry, DS459 (n 1); European Union: Certain Measures Relating to the Energy Sector, DS476 (n 1).

28 See Commission, Energy, 'Single Market for Gas and Electricity' < http:/ / ec.europa.eu/ energy/gas_electricity/legislation/legislation_en.htm> accessed 20 July 2014.
} 
ments in respect of granting of access to natural gas and electricity network capacity by transmission service operators'. ${ }^{29}$

\subsection{Disputes on anti-dumping measures}

The last type of EU energy disputes in the WTO concerns antidumping measures.

In 2013, the EU introduced anti-dumping duties on imports of biodiesel from Argentina and Indonesia. ${ }^{30}$ The EU stated that its investigation showed that 'Argentine and Indonesian companies benefit from an unfair advantage because they have access to raw materials at prices that are artificially low compared to the world market prices available for the EU biodiesel producers'. ${ }^{31}$ The EU argues that the world price of raw materials, soya beans, soybean oil and palm oil, is much higher than the price of these goods in Argentina and Indonesia as those countries charge high export taxes on their exports (Argentina on soya beans and soya bean oil, and Indonesia on palm oil). ${ }^{32}$ Such taxes make exports less attractive, leaving more goods on the domestic market and thus lowering their domestic price. The EU claims that it imposed antidumping duties in accordance with WTO law, and applied the 'lesser duty rule' so that 'the duty rates to be imposed will be lower than the dumping margin itself and will instead be pitched at a level calculated sufficient to offset the injury suffered by the industry'. ${ }^{33}$ These definitive anti-dumping measures are scheduled to apply for five years. The EU considers that they will restore 'fair competition [, but also] ensure the continued development of an innovative green energy sector in the EU' ${ }^{34}$ Basically, this merges the aim of fair international competition, environmental aims, but also the aim of stimulating domestic industry. Argentina, thus, claims that the duties are protectionist and intended to protect uncompetitive domestic producers. ${ }^{35}$ Indonesia is challenging both these anti-dumping duties and the EU Anti-Dumping Regulation. ${ }^{36}$

\footnotetext{
29 WTO, European Union and its Member States: Certain Measures Relating To The Energy Sector-Request for Consultations by the Russian Federation (30 April 2014) WT/DS476/1.

30 Council Implementing Regulation (EU) No 1194/2013 of 19 November 2013 imposing a definitive anti-dumping duty and collecting definitively the provisional duty imposed on imports of biodiesel originating in Argentina and Indonesia [2013] OJ L315/2.

31 Commission, 'Press Release: EU to Impose Definitive Anti-dumping Duties on Biodiesel from Argentina and Indonesia' 21 November 2013 <http://europa.eu/rapid/press-release_ IP-13-1140_en.htm> accessed 20 July 2014.

32 ibid.

33 ibid.

34 ibid.

35 Reuters, 'Argentina Files Complaint to WTO Over EU Biodiesel Import Duties', 19 December 2013 <http://www.reuters.com/article/2013/12/19/argentina-wto-biodiesel-idUSL2NOJYOV920131219> accessed 14 July 2014.

36 Council Regulation (EC) No 1225/2009 of 30 November 2009 on protection against dumped imports from countries not members of the European Community [2009] OJ
} 
The EU also has in force anti-dumping duties on imports from Russia which indirectly concern energy. Namely, Russia is challenging the EU Anti-Dumping Regulation and definitive duties applied to certain goods (eg ammonium nitrate, welded tubes and pipes of iron or non-alloy steel, etc), and it specifically objects to the 'cost adjustment method' where the EU does not accept the cost data provided by the foreign producer or exporter and provides its own estimate of the 'market' cost. ${ }^{37}$ In particular, Russia objects that the EU rejected the reported manufacturing costs of Russian goods, including the costs of energy (gas and electricity), and replaced these with its own estimate of manufacturing and energy costs. ${ }^{38}$

The EU also has in force anti-dumping duties on imports of biodiesel from the US. ${ }^{39}$ These duties were supposed to expire on 11 July $2014,{ }^{40}$ but the Commission received a request for review which means that they might remain in force. ${ }^{41}$ The US has not challenged these duties.

\section{Conclusion}

This report has given a brief overview of the seven currently pending WTO disputes which challenge parts of EU energy law. There are other energy-related disputes which have been dealt with in other fora, and these could reach the WTO at any time. For example, the disagreement concerning the application of the European Emissions Trading Scheme (ETS) to aviation, ${ }^{42}$ applicable to all flights landing or departing from an EU airport, was at the core of a case before the European Court of Justice. ${ }^{43}$ Now, the International Civil Aviation Organisation (ICAO) has been given the task to resolve this issue by adopting international rules on aviation emissions. ${ }^{44}$

L343/51; WTO, European Union: Anti-Dumping Measures On Biodiesel From Indonesia - Request for Consultations by Indonesia (10 June 2014) WT/DS480/1.

37 WTO, European Union: Cost Adjustment Methodologies and Certain Anti-Dumping Measures on Imports from Russia - Request for Consultations by the Russian Federation (23 December 2013) WT/DS474/1.

38 ibid.

39 Council Regulation (EC) No 599/2009 of 7 July 2009 imposing a definitive anti-dumping duty and collecting definitively the provisional duty imposed on imports of biodiesel originating in the United States of America [2009] OJ L179/26; Commission Regulation (EC) No $193 / 2009$ imposing a provisional anti-dumping duty on imports of biodiesel originating in the United States of America [2009] OJ L67/22.

40 Notice of the impending expiry of certain anti-dumping measures [2013] OJ C289/12.

41 Notice of initiation of an expiry review of the anti-dumping measures applicable to imports of biodiesel originating in the United States of America [2014] OJ C217/14.

42 Directive 2008/101/EC of the European Parliament and of the Council of 19 November 2008 amending Directive 2003/87/EC so as to include aviation activities in the scheme for greenhouse gas emission allowance trading within the Community [2009] OJ L8/3.

43 Case C-366/10 Air Transport Association of America v Secretary of State for Energy and Climate Change, judgment of 21 December 2011.

44 ICAO Resolution A38-18: Consolidated statement of continuing ICAO policies and 
EU energy law consists of a plethora of internal and external energy measures that are motivated by a number of interests, the most important being to ensure a competitive internal market, environmental protection, and energy security. The EU will certainly continue pursuing all of these aims in various ways. First, it is expected that the EU will continue focusing on a diversification of energy sources. This could be done by measures which further stimulate the development and production of biofuels and other renewable energy sources. Second, the EU could try to make its internal market more integrated when it comes to energy, as the movement of these goods within the EU is still very limited and it is possible to have a surplus of energy in one region and a lack of it in another. For example, it was recently proposed to create a European energy union which would address this fragmentation of the EU energy market. ${ }^{45}$ Third, the EU will try to ensure a greater variety of fossil fuel suppliers. For example, the currently negotiated agreement with the US, the Transatlantic Trade and Investment Partnership (TTIP), can also be used for gaining access to US natural gas. The US has traditionally not been an exporter of natural gas largely because it did not have enough of this resource for its own needs, so the export rules have been quite restrictive. New technologies, horizontal drilling and hydraulic fracturing (fracking), have enabled the US to start extracting its abundant shale gas so the US could soon turn into a larger exporter. Under the current legal regime, exports are possible with the approval of a federal agency, but the procedure is simpler if there is a free trade agreement, ${ }^{46}$ so the TTIP would facilitate exports to the EU. ${ }^{47}$ It remains to be seen how much the EU would be willing to rely on US shale gas considering that there are significant concerns about the environmental impact of fracking. ${ }^{48}$

practices related to environmental protection - Climate change, November 2013, particularly Art 19.

45 Christian Oliver, 'EU Energy Market: Pipe Dream' Financial Times (London, 9 July 2014)<http://www.ft.com/intl/cms/s/0/c6dd6c38-ea3c-11e3-afb3-00144feabdc0. html\#axzz381xT2dpH> accessed 20 July 2014.

$46 \quad 15$ US Code $\S 717 \mathrm{~b}$ - Exportation or importation of natural gas; LNG terminals. On whether the US should be exporting natural gas and oil to countries with which it does not have an FTA, see Cathleen Cimino and Gary Clyde Huffbauer, 'US Policies Toward Liquefied Natural Gas and Oil Exports: An Update' (July 2014) Peterson Institute for International Economics Policy Brief, No PB14-19 <http://www.piie.com/publications/pb/pb14-19.pdf> accessed 21 July 2014.

47 Daniel S Hamilton, 'Transatlantic Challenges: Ukraine, TTIP and the Struggle to be Strategic' (2014) 52 (Annual Review) Journal of Common Market Studies 25.

48 Commission, 'Recommendation 2014/70/EU of 22 January 2014 on minimum principles for the exploration and production of hydrocarbons (such as shale gas) using highvolume hydraulic fracturing' [2014] OJ L 39/72; Commission, 'Communication on the exploration and production of hydrocarbons (such as shale gas) using high volume hydraulic fracturing in the EU' COM/2014/023 final/2; Commission Staff Working Document Impact Assessment, SWD/2014/021 final. 
All of the existing and future energy measures can cause obstacles to trade and thus have strong external effects on current or potential trading partners. Energy is covered by WTO law so that it is always necessary to check WTO compliance before adopting a measure. In that respect, diversification of energy sources is acceptable to the extent that it could be subsumed under a permitted justification (eg security, ${ }^{49}$ preservation of exhaustible natural resource ${ }^{50}$ ), but not if its aim is to protect domestic production so as to reduce imports. In general, improving market efficiency, protecting the environment and energy security are valuable aims, but they should not be used to conceal protectionism.

49 Art XXI GATT.

50 Art XX g) GATT. 
